\title{
The effect of the "Rizotorfin" inoculant on moisture consumption and productivity of yellow melilot
}

\author{
Natalya L. Kurachenko ${ }^{1}$, and Valentina L. Bopp ${ }^{1, *}$ \\ ${ }^{1}$ Krasnoyarsk State Agrarian University, Institute of Agroecological Technologies, 660049 \\ Krasnoyarsk, Russia
}

\begin{abstract}
A significant part of the livestock feed in Siberia is obtained from yellow melilot (Melilotus officinalis Pall.) - a perennial legume crop. In addition to its nutritional benefits, melilot is valuable as a source of biological nitrogen in soil and has phytosanitary qualities. To increase the productivity of the crop with considerate consumption of moisture resources, it was proposed to use inoculation of melilot seeds with the nodule bacteria compound - "Rizotorfin". It was proved in a field experiment that the "Rizotorfin" treatment of melilot seeds contributes to a more reasonable expenditure of soil moisture, the evapotranspiration coefficient characterizing the average moisture consumption per 1 ton of crop's green mass is reduced by 0.7 relative to the control variant plants. The root system develops better, the morphometric parameters of the experimental plants are $25-31 \%$ higher than those of plants not treated with "Rizotorfin". The green mass yield of the experimental plants is $28-33 \%$ higher than in the control variant.
\end{abstract}

\section{Introduction}

In solving the problems of modern agriculture that are associated with a high anthropogenic load on ecosystems, it is necessary to use biological approaches that increase the productivity of agricultural plants and the preservation and restoration of soil fertility. In this regard, yellow melilot (Melilotus officinalis Pall.), which has a number of positive qualities, is of particular importance. The range of melilot's application is very wide. It is highly evaluated as a fodder crop for grazing and haying, since it makes high-protein feed [1,2]. Melilot is a source of nitrogen enrichment of soil [3]. Studies [4] proved the advantage of culture in restoring of the bioresource potential of degraded meadows and pastures. Its anti-erosion, phytomeliorative, phytosanitary properties are known. The passed experiments [5] showed the allelopathic potential of melilot in controlling the weeds: water extracts of Melilotus officinalis significantly inhibited seed germination and development of the Echinochloa crusgalli L., Poa annua L., Veronica persica Poir seedlings. One research [6] substantiated biological effect of sublethal concentrations of melilot extract in relation to the life cycle of Spodoptera littoralis.

* Corresponding author: vl_kolesnikova@mail.ru 
A significant part of livestock feed in Siberia is obtained from yellow melilot. A wide ecological amplitude allows the melilot to grow on various types of soils, and high winter hardiness and drought tolerance provides high and stable yield [7]. However, in order to realize the biological potential of culture in production, a sound approach to the technology of cultivation is required, which allows more efficient use of the resource of the soil-climatic zone. Of particular scientific and practical interest are those studies that are aimed at studying the effect of the "Rizotorfin" product on root growth and melilot's moisture consumption a culture with intense absorption of moisture. For the conditions of the agricultural part of the Krasnoyarsk Krai, such studies are new and they expand the possibilities of using biologization elements in the cultivation of fodder crops.

In order to increase the productivity of fodder crop rotation and the reproduction of soil fertility, an experiment was conducted of studying the effect of inoculation of yellow melilot seeds with the "Rizotorfin" product on the moisture consumption and green mass yield.

\section{Materials and methods}

The studies were conducted under field conditions in the Krasnoyarsk forest-steppe. Objects of research: nodule bacteria compound "Rizotorfin", yellow melilot of the "KATEK" variety, ordinary low-power medium-loamy chernozem. The experimental design included the following variants: 1 . Melilot without seed inoculation (control variant); 2 . Melilot with the "Rhizotorfin" seed inoculation. Dosage form of the product: "Rhizotorfin" package item on gamma-sterile peat. Seed treatment with the "Rhizotorfin" was carried out on the day of sowing at the rate of 1 liter of solution per $100 \mathrm{~kg}$ of seeds. Agro-technical measures for cultivation of crops were consistent with the zonal recommendations [8]. The plot area was 2 ha. The forecrop was the potato crops. Melilot sowing was carried out by a machine-tractor unit: Jhon Deere 8310R tractor + small-seeded pneumatic seeder Turbo-JetSuper 8 installed on a Lemken Rubin- 6 cultivator, discs were raised near the cultivator, after sowing, the seeds were rolled down by the cultivator rollers. Fertilizers and plant protection products were not used.

The soil of the experimental plot was characterized by a high humus content in the soil layer of $0-20 \mathrm{~cm}(8.6-9.4 \%)$ and increased in the layer of $20-40 \mathrm{~cm}(7.1-7.4 \%)$, neutral environmental reactions $(\mathrm{pH}$ 6.6-6.8). The concentration of basic nutrients before sowing varied from high to very high. The bulk density of the arable layer corresponded to the optimal parameters $-0.95-1.11 \mathrm{~g} / \mathrm{cm}^{3}$.

Samples were taken for soil moisture content and bulk density in layers of 0-20 and 20$40 \mathrm{~cm}$. Humidity was determined by the thermal weight method, and Kachinsky bulk density method [9]. The sampling period was in June, July, August, September. The yield of green mass of melilot was taken into account according to the experimental variants in the $1^{\text {st }}$ and $2^{\text {nd }}$ year of plants' life. The results were processed by analysis of variance and descriptive statistics [10].

\section{Results and discussion}

The main awareness in agricultural production is moisture, which is labile and sufficient to maintain the life of cultivated plants and create an appropriate crop. Studies have shown that the reserves of productive moisture in the $0-40 \mathrm{~cm}$ layer of chernozem varied to a small and medium degree $(\mathrm{Cv}=19-29 \%)$ and changed from bad to good during the season. The combined action of weather conditions and crops determined the nature of dynamics of productive moisture reserves in the soil. The weather conditions of the growing season were 
characterized by excessive moisture in May-August (average excess of the standard by 27$39 \mathrm{~mm}$ ) and a sharp precipitation decrease in September (16 $\mathrm{mm}$ below the standard).

The average seasonal values of moisture reserves in the $0-40 \mathrm{~cm}$ layer of melilot crops soil were $33 \mathrm{~mm}$. Inoculation of melilot seeds with "Rizotorfin" contributed to a decrease in productive moisture reserves to $28-29 \mathrm{~mm}$. The most intense moisture consumption by the melilot roots in this variant manifested itself from the July period, reaching a maximum in the third and first decade of August and September, respectively. The "Rizotorfin" seed treatment in the July period reduced moisture reserves by $5-14 \mathrm{~mm}$ in $0-20 \mathrm{~cm}$ of the arable layer $\left(\mathrm{HCP}_{05}=4.3\right)$. Studies [11] proved that the July period is characterized by a significant decrease in the available moisture reserves in the root-inhabited layer of agricultural crops in the conditions of the Krasnoyarsk forest-steppe.

Melilot forms a powerful root system to great depths and divides it into countless small areas of granular and lumpy type [12]. These conditions contribute to the intensive moisture absorption by the roots. The "Rizotorfin" seed treatment stimulates development of the melilot root system, which has a draining effect on the arable and subsurface layers of the soil. Data on water consumption for transpiration and evaporation from the surface of the soil confirm this statement (Table 1). The total melilot moisture consumption is estimated at 291 $\mathrm{mm}$. Inoculation of seeds with "Rizotorfin" increases water consumption by $6 \%$. The formation of aboveground phytomass here is determined mainly by summer precipitation, because the soil moisture ratio makes up only to $17 \%$ in the water consumption.

Table 1. Moisture supply and moisture consumption of melilot crops in the $2^{\text {nd }}$ year of life, mm (0-40 $\mathrm{cm})$.

\begin{tabular}{|c|c|c|c|c|c|c|}
\hline \multirow{2}{*}{ Experimental variant } & \multicolumn{2}{|c|}{ Moisture reserve } & \multirow{2}{*}{ PGS } & MS & MC & \multirow{2}{*}{$\mathbf{K}_{\mathbf{e}}$} \\
\cline { 2 - 7 } & in spring & in autumn & & & & \\
\hline Melilot & 72 & 65 & 303 & 375 & 291 & 9.1 \\
\hline Melilot + "Rizotorfin" & 70 & 55 & 303 & 373 & 308 & 8.4 \\
\hline
\end{tabular}

Note: PVS - precipitation during the growing season, MS - moisture supply, MC moisture consumption, $\mathrm{K}_{\mathrm{e}}$ - evapotranspiration coefficient

The evapotranspiration coefficient, which is characterizing the average moisture consumption per 1 ton of crop's green mass is 9.1. The technology of melilot cultivation with inoculation of seeds with "Rizotorfin" determines a more economical expenditure of productive moisture from $0-40 \mathrm{~cm}$ of the soil layer (8.4).

Melilot, like other leguminous perennial crops, slowly develops in the year of sowing. In the first year of life, the yield of melilots' green mass in the control variant was $10 \mathrm{t} / \mathrm{ha}$. The "Rizotorfin" seed treatment had a positive effect on the growth and development of plants, which contributed to an increase in the yield of green mass by $28 \%\left(\mathrm{HCP}_{05}=2,3\right)$ (Fig. 1).

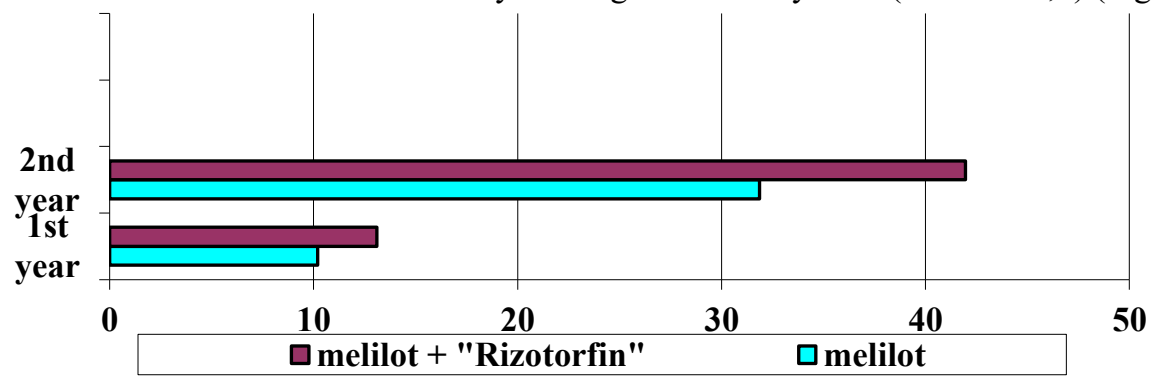

Fig. 1. Impact of "Rizotorfin" on the formation of melilot's green mass, $\mathrm{t} / \mathrm{ha}$. 
In the second year of plant life, two-timed mowing of melilot's green mass were obtained. Plants were mowed in the budding phase and the beginning of flowering. The largest yield in total (for two-timed mowing) was also formed on plots with seed inoculation with a biological product of nodule bacteria $-42 \mathrm{t} / \mathrm{ha}$. Plant productivity was $33 \%$ higher in relation to the control variant $\left(\mathrm{HCP}_{05}=10.5\right)$. of melilot yield, in our opinion, is due to the fact that the basis of "Rizotorfin" is the nodule bacteria, which are able to enter into symbiosis with a legume plant. As a result, nodules are being formed on the roots that are capable of fixing molecular nitrogen from the air and converting it into a form that is accessible for plants. Thanks to this unique process, the plant receives the necessary amount of nitrogen from the air for its growth and development and that is "prolonged" throughout the entire growing season. This process allows plants to become "self-sufficient" for a given nutrient. It can be assumed that the absorption of nitrate nitrogen was more intense in the variants with "Rizotorfin", than in the control variant of the experiment [13].

Taking into account morphometric parameters of the melilot roots of the $1^{\text {st }}$ year of life showed a significant impact of the nodule bacteria compound on development of the absorbing surface (Fig. 2, Table 2).

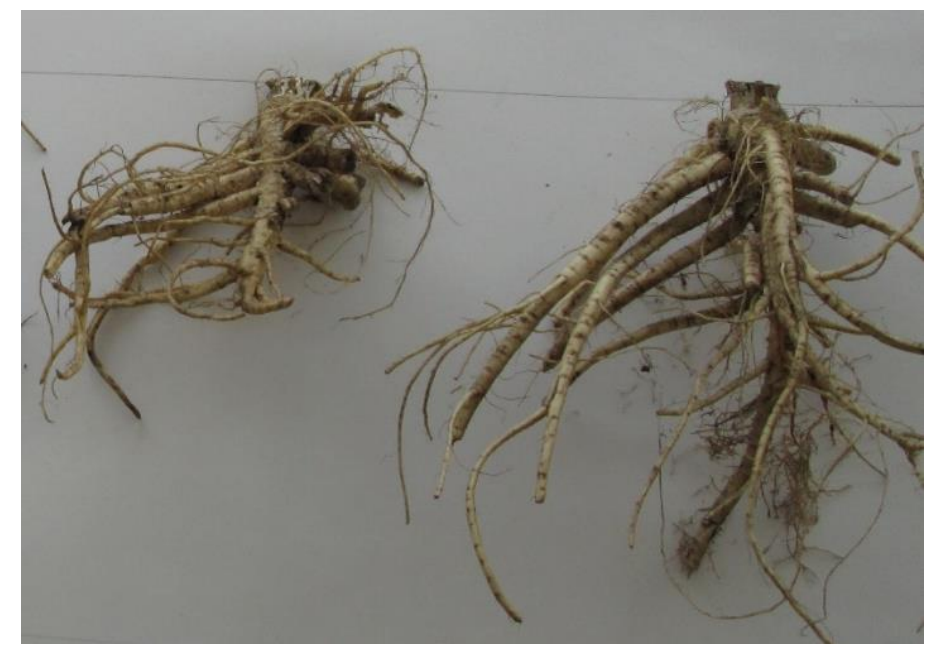

Fig. 2. Impact of "Rizotorfin" on the formation of the melilot's root system (on the left - the control variant, on the right - inoculation with "Rizotorfin").

Inoculation of clover seeds with "Rizotorfin" increased the root collar diameter by $25 \%$, the root volume in the $0-20 \mathrm{~cm}$ of the soil layer - by $31 \%$, the root surface area - by $27 \%$, and the total root length - by $23 \%$. The smallest significant difference confirms significant differences between the means.

Table 2. Impact of "Rizotorfin" on morphometric indicators of the melilot's root system in 0-20 cm of soil layer.

\begin{tabular}{|c|c|c|c|c|}
\hline $\begin{array}{c}\text { Experimental } \\
\text { variant }\end{array}$ & $\begin{array}{c}\text { Root collar } \\
\text { diameter, } \\
\mathbf{m m}\end{array}$ & $\begin{array}{c}\text { Root } \\
\text { volume, } \mathbf{c m}^{\mathbf{3}}\end{array}$ & $\begin{array}{c}\text { Root surface } \\
\text { area, } \mathbf{c m}^{\mathbf{2}}\end{array}$ & $\begin{array}{c}\text { Total root } \\
\text { length, } \mathbf{m} / \mathbf{m}^{\mathbf{2}}\end{array}$ \\
\hline Melilot & 20.5 & 68.8 & 74.3 & 6.4 \\
\hline $\begin{array}{c}\text { Melilot + } \\
\text { "Rizotorfin" }\end{array}$ & 25.7 & 90.0 & 94.5 & 7.9 \\
\hline$H C P_{05}$ & 2.3 & 10.3 & 15.4 & 0.7 \\
\hline
\end{tabular}




\section{Conclusion}

Hence, cultivation of yellow melilot with seed inoculation with the biological compound "Rizotorfin" contributes to a more reasonable expenditure of soil moisture due to the predominant use of summer precipitation, determines intensive development of the absorbing surface of the root system and benefits to increase of the green mass yield of the crop by 28 $33 \%$, compared to the control variant.

\section{References}

1. N. I. Kashevarov, V. P. Danilov, R. I. Polyudina, A. M. Mustafin et al, Agrotekhnologii proizvodstva kormov v Sibiri [Agricultural technologies of feed production in Siberia]. (Siberian Federal Scientific Center for Agrobiotechnology of the Russian Academy of Sciences, Novosibirsk, 2013)

2. E. R. Shukis, Kormovye kul'tury na Altae [Feed crops in Altai], 147 (GNU Altajskij NIISKH Rossel'hozakademii, Barnaul, 2013)

3. M. J. Dornbusch, R. F. Limb, C. K. Gasch, Rangeland Ecology and Management 71, 691, 2018. DOI: 10.1016/j.rama.2018.06.009

4. B. Nasiyev, Research Journal of Pharmaceutical Biological and Chemical Sciences 7, 245,2016

5. C. X. Wu, X. X. Guo, Z. H. Li, Y. X. Shen, Allelopathy Journal 25, 173, 2010

6. M. A. I. Ahmed, A. M. M. Ahmed, A. M. A. R. M. Amro, Entomology and Applied Science Letters 5, 112, 2018

7. V. K. Dridiger, Donnik [Melilot] (Agrorus, Stavropol, 2014)

8. R. V. Alkhimenko, A. M. Berzin, A. V. Bobrovsky, V. L. Bopp et al, Sistema zemledeliya krasnoyarskogo kraya na landshaftnoj osnove [The agricultural system of the Krasnoyarsk Territory on a landscape basis] (Polikor, Krasnoyarsk, 2015)

9. L. N. Alexandrova, O. A. Naydenova, Laboratorno-prakticheskie zanyatiya po pochvovedeniyu [Laboratory and practical classes in soil science] (Kolos, Leningrad, 1986)

10. B. A. Dospekhov, Metodika polevogo opyta [The methodology of field experience] (Alliance, Moscow, 2014)

11. N. L. Kurachenko, A. A. Kartavykh, Zemledelie 2, 17 (2017)

12. N. L. Kurachenko, S. N. Solodchenko, V. N. Romanov, V. M. Litau, Agrarian science 10, 15 (2008)

13. N. L. Kurachenko, V. L. Kolesnikova, V. S. Sheremetov, Bulletin of KrasGAU 2, 16 (2015) 